\title{
$\mathrm{CO}_{2}$ 수송선 저장탱크의 $\mathrm{BOG}$ 측정 실험 및 회수에 관한 연구
}

\author{
박진우, 김동선, 고민수 ${ }^{\dagger}$, 조정호* \\ 공주 대학교 화학공학부 \\ 330-717 충남 천안시 서북구 천안대로 1223-24 \\ †삼성 중공업, 조선해양연구소 \\ 656-710 경남 거제시 장평3로 80
}

\section{A Study on the Experimental Measurements and Its Recovery for the Rate of Boil-Off Gas from the Storage Tank of the $\mathrm{CO}_{2}$ Transport Ship}

\author{
Jin-Woo Park, Dong-Sun Kim, Min-Su Ko ${ }^{\dagger}$, and Jung-Ho Cho* \\ Department of Chemical Engineering, Kongju National University \\ 1223-24 Cheonan-daero, Seobuk-gu, Cheonan-si, Chungnam 330-717, Korea \\ ${ }^{\dagger}$ Samsung Heavy Industries, Marine Research Institute \\ 80 Jangpyeong-3ro, Geoje-si, Gyeongnam 656-710, Korea
}

(Received for review November 22, 2013; Revision received December 11, 2013; Accepted December 11, 2013)

\section{요 약}

화석연료로부터 에너지를 얻을 때, 연소반응에 의해 이산화탄소가 생성되어 진다. 이렇게 이산화탄소의 배출이 늘어나게 되면 지구온난화 문제가 더욱 심각해지게 된다. 따라서 이를 방지하기 위한 이산화탄소 포집 및 저장기술(carbon capture and storage, CCS) 개발이 요구되고 있다. 하지만 액화 이산화탄소를 수송 시 여러 문제로 인해 지속적으로 BOG (boil-off gas)가 발생하게 된다. 본 연구에서는 $40 \mathrm{~m}^{3}$ 저장 탱크 2대에 액화 이산화탄소를 주입하여 압력변화 및 외부열과 선적, 하역 시 발생하는 BOG의 양과 조성을 30 일 간 측정하였다. 측정한 결과 $16,040 \mathrm{~kg}$ 의 BOG가 발생하였으며, 조성은 $\mathrm{CO}_{2} 99.95 \%$, $\mathrm{N}_{2} 0.05 \%$ 인 것을 알 수 있었다. 또한 상용성 모사기인 PRO/II with PROVISION 9.2를 이용하여 발생한 BOG를 증기 재압축 냉동사이클을 통해 재액화 하는 전산모사를 수행하였다. 그 결과 냉동사이클의 총 순환유량은 $42.07 \mathrm{~kg} / \mathrm{h}$, 응축기 설비의 소 모량은 $48.85 \mathrm{~kg} / \mathrm{h}$ 가 나오는 것을 알 수 있었다.

주제어 : 이산화탄소, 이산화탄소 포집 및 저장기술, 보일러-오프 가스, 재액화, 냉동사이클

\begin{abstract}
CO}_{2}$ is generated by the combustion reaction, when getting the energy from fossil fuel. If the carbon dioxide emissions increases more, the global warming problem will become more serious. CCS (carbon capture storage) needs to be developed for the prevention of this. When liquefied $\mathrm{CO}_{2}$ is transported, $\mathrm{BOG}$ (boil-off gas) is generated because of several problems. In the study, by injecting liquefied $\mathrm{CO}_{2}$ in two tanks which contains $40 \mathrm{~m}^{3}$ each, the amount of BOG and its composition were measured during 30 days when generating pressure changes and external heat, loading, unloading. In result, 16,040 $\mathrm{kg}$ of BOG was generated and the composition has been found out to be $99.95 \% \mathrm{CO}_{2}$ and $0.05 \% \mathrm{~N}_{2}$. Also, we conducted simulation process for reliquefaction of generated BOG with vapor compression cycle using the PRO/II with PROVISION version 9.2. As a result, the refrigeration cycle of the total circulation flow rate was $42.07 \mathrm{~kg} / \mathrm{h}$ and the condenser utility consumption was $48.85 \mathrm{~kg} / \mathrm{h}$.
\end{abstract}

Keywords : $\mathrm{CO}_{2}, \mathrm{CCS}, \mathrm{BOG}$, Reliquefaction, Refrigeration cycle

\section{1. 서 론}

우리가 사용하는 대부분의 에너지는 탄화수소로 이루어진

\footnotetext{
* To whom correspondence should be addressed. E-mail: jhcho@kongju.ac.kr doi: $10.7464 /$ ksct.2014.20.1.001 pISSN 1598-9721 eISSN 2288-0690 http://cleantech.or.kr/ct/
}

화석연료(석유, 석탄, 천연가스 등)를 태워 나오는 열로 얻어 지며 연소과정에서 탄화수소는 산소와 반응하여 이산화탄소 와 물로 변한다. 즉 화석연료로부터 에너지를 얻으면 반드시 이산화탄소가 배출되게 된다. 지구온난화가 대두되기 이전 시 기에는 발생된 이산화탄소가 지구식물자원의 선순환 구조에 의해 적절히 소화되어 균형을 이루었다. 그러나 급격한 화석 연료 사용으로 그 균형이 깨져 온난화문제가 발생되었다. 화 
석연료 사용이 늘어나는 만큼 필수 불가결하게 이산화탄소의 배출량은 늘어날 것으로 판단되며 지구온난화를 방지하기 위 해서는 이산화탄소 포집 및 저장기술(Carbon Dioxide Capture and Sequestration, CCS) 개발이 요구되고 있다.

즉, 이산화탄소를 대량발생원으로부터 포집한 후 압축, 액 화 및 수송 등의 과정을 거쳐 육상이나 해양의 지중에 안전하 게 저장하거나 유용한 물질로 전환함으로써 온실가스의 배출 을 억제하려는 CCS가 온실가스 감축의 유용한 대안으로서 점차 부각되고 있다. $\mathrm{CCS}$ 기술은 이산화탄소가 대기 중에 배 출되기 전에 회수를 한 후 수송하여 격리시키는 기술이며 크 게 이산화탄소 포집기술과 이산화탄소 수송기술 및 이산화탄 소 저장기술로 이루어져 있다[1].

이산화탄소 포집기술은 크게 연소공정을 거친 후 발생한 배기가스 내 포함되어 있는 이산화탄소와 질소를 분리하는 연소 후 포집기술과 화석연료로부터 수소와 일산화탄소 등의 합성가스를 제조한 후 수소의 수율을 높이고자 일산화탄소와 수증기를 이용한 수성 가스 전화 반응을 거치는 과정에서 발 생한 이산화탄소를 분리하는 연소 전 포집기술이 있으며, 연 소에 필요한 공기로부터 고순도 산소를 분리하여 연소기에 공급함으로써 연소효율 향상 및 연소과정 후 배출되는 가스 중 이산화탄소의 농도를 높여 회수가 용이하도록 하는 순산 소 연소기술로 구분할 수 있다. 또한, 이산화탄소 수송기술은 회수한 이산화탄소를 격리 또는 저장하는 장소까지 수송하는 기술이다.

본 연구에서는 수송 중 여러 변수에 의해 지속적으로 발생 하는 boil-off gas (BOG)를 측정하고 공정모사기를 이용하여 이를 처리하는 것을 목적으로 하였다[2].

\section{2. 실 험}

\section{1. 개 요}

Figure 1은 이산화탄소를 수송 시 파이프라인과 선박을 이 용할 경우에 대해 운반거리 대비 비용을 비교한 것으로, 이산 화탄소 포집원으로부터 운반 거리가 길어질수록 파이프라인 에 비해 운반선의 경제성이 점차 높아짐을 알 수 있다[3].

육상에서 액화공정을 거침으로서 불순물이 대부분 제거된 고순도의 액화 이산화탄소를 선박에 옮겨 실은 후 수일 내지 수십일 동안 항해하는 과정에서 선박의 진동에 의한 유체의 마찰이나 외부열의 침투 또는 선적, 하역으로 인해 지속적으

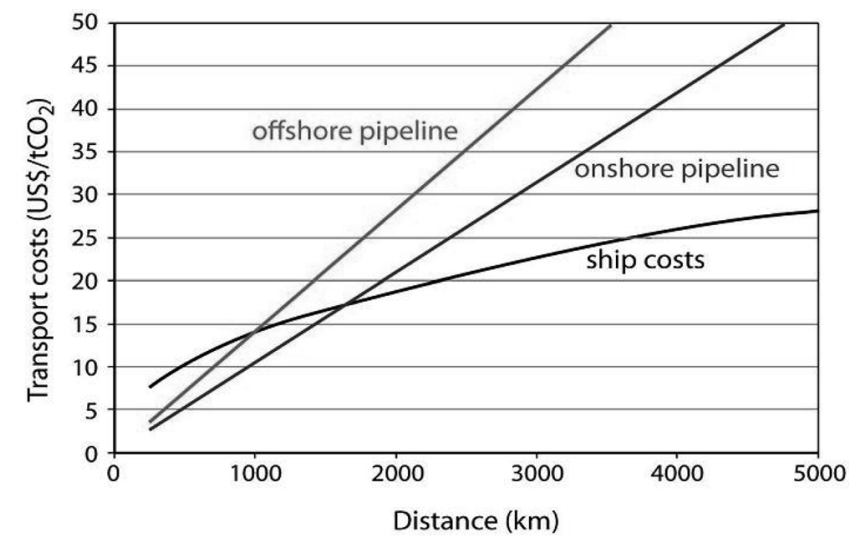

Figure 1. The cost according to $\mathrm{CO}_{2}$ transportation distance.

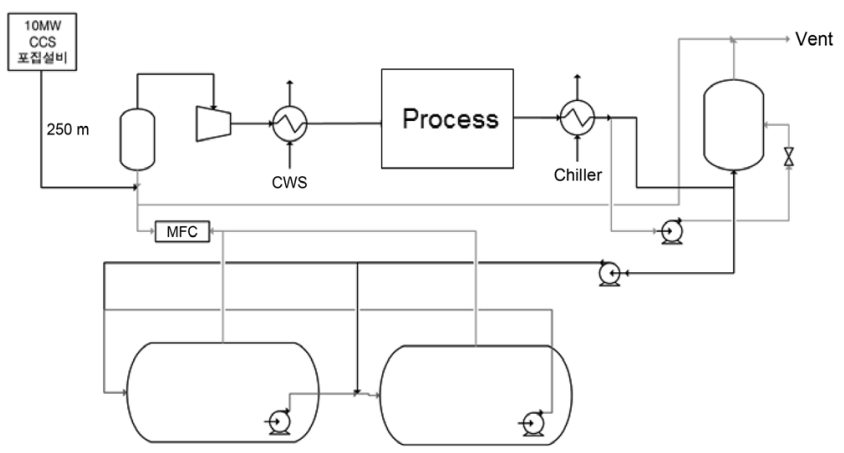

Figure 3. Process diagram of carbon capture and storage.

로 BOG가 발생하는데 이를 방치할 경우 압력용기의 보호를 위해 대기 중으로 이산화탄소를 방출해야 하는 상황이 발생 하게 된다. 따라서 Figure 2와 같이 보일-오프 레이쇼(boil-off ratio, BOR)에 값에 의해 적절한 처리공정을 결정할 수 있다 [4]. BOR 값이 크면 불응축 가스 여부에 따라 멤브레인과 재 액화 공정으로 처리할 수 있으며, BOR 값이 작으면 흡수 또는 흡착 공정으로 처리할 수 있다.

Figure 3은 운반선 CCS의 대략적인 공정도로써 아래쪽 section은 이산화탄소를 저장하는 탱크 즉 BOG가 발생하는 지점 이며, 위쪽 section은 발생한 BOG의 양과 조성에 따라 효율적 인 공정을 적용하여 처리하는 지점이다.

\section{2. 실험 방법 및 결과}

실험에 앞서 저장 탱크의 운전 조건을 Figure 4 와 같이 이

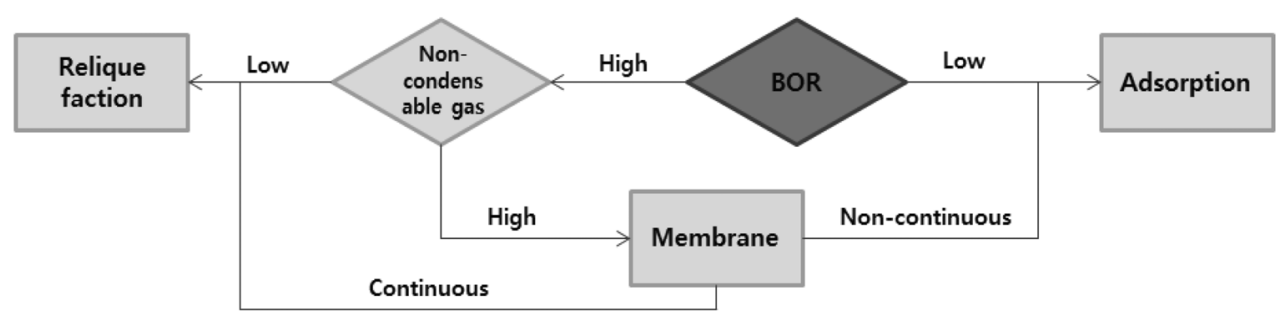

Figure 2. A diagram of treatment process. 


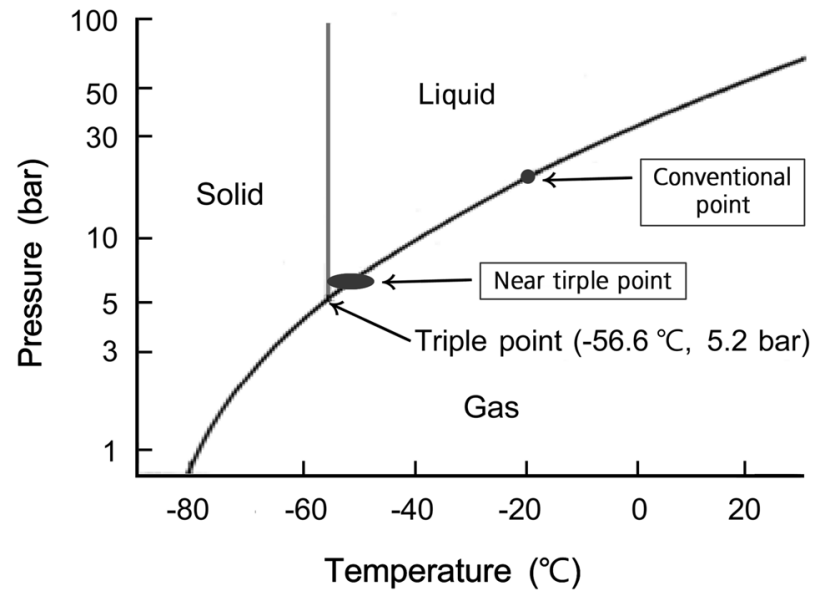

Figure 4. Phase equilibrium graph of $\mathrm{CO}_{2}[5]$.

Table 1. Comparison of the triple point and conventional point

\begin{tabular}{l|c|c}
\hline & Triple point & Conventional point \\
\hline \hline Temperature $\left({ }^{\circ} \mathrm{C}\right)$ & $-55--45$ & -20 \\
\hline Pressure (bar) & $6-7$ & 20 \\
\hline Density & High & Low \\
\hline Storage efficiency & High & Low \\
\hline Power & High & Low \\
\hline Dry ice possibility & High & Low \\
\hline Tank cost & Low & High \\
\hline
\end{tabular}

산화탄소 상평형 그래프를 이용하여 설정하였다. 여기서 컨벤셔 널 포인트는 저장과 운반 시 통상적으로 이용하는 운전 조건 이며, 니어 트리플 포인트는 삼중점 근처 조건이며 Table 1과 같이 두 지점을 비교하였다.

삼중점 지점은 비교적으로 온도가 낮아 밀도가 올라가게

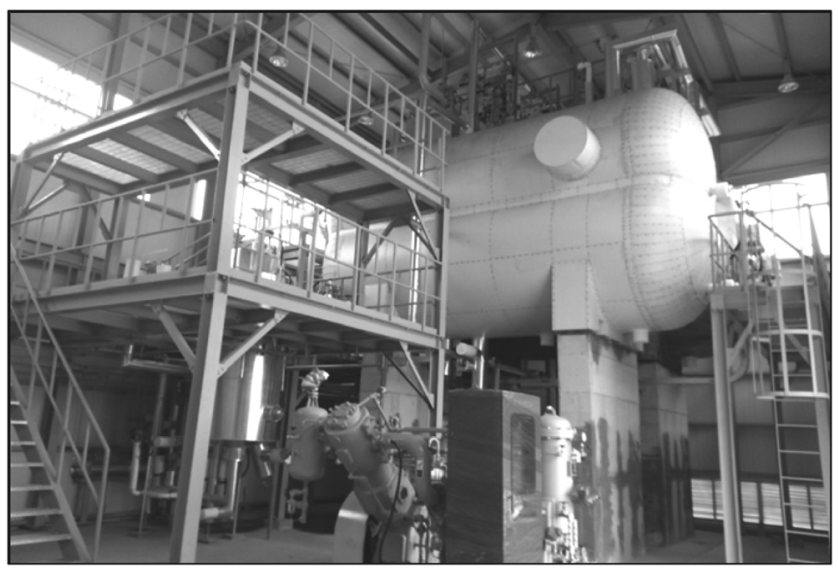

Figure 5. Equipments used in the experiment.

된다. 때문에 부피당 저장할 수 있는 양이 많아지게 되고, 압 력이 상대적으로 낮아 저장탱크의 비용을 줄일 수 있는 장점 이 있다.

하지만 온도를 약 $-50{ }^{\circ} \mathrm{C}$ 까지 낮추기 위해서는 그만큼의 많 은 동력이 필요로 하게 되며, 삼중점 근처이기 때문에 dry ice 생성 가능성이 증대하게 되는 단점이 있다[5].

따라서 2 개의 포인트 사이에서 기술적/경제적인 측면을 고 려하여 효율적인 운전 조건을 설정해야 한다. 하지만 두 포인 트 사이의 모든 조건에서 한 번에 실험하는 것은 상당히 어렵 기 때문에 우선 컨벤셔널 포인트 주위에서 운전 조건은 -25 $\sim-18{ }^{\circ} \mathrm{C}, 16 \sim 20 \mathrm{bar}$ 운전 시간은 30 일로 하여 실험을 수행 하였다.

Figure 5는 실제로 사용한 실험 장치이며, 2 대의 tank로 이루 어져 있으며, 각각 용적은 $40 \mathrm{~m}^{3}$ 이다.

Figure 6은 실험 장치의 공정도이다. 용량이 20 ton인 tank lorry 2 대를 이용하여 이산화탄소 $99.95 \mathrm{vol} \%$ 에 질소와 수분

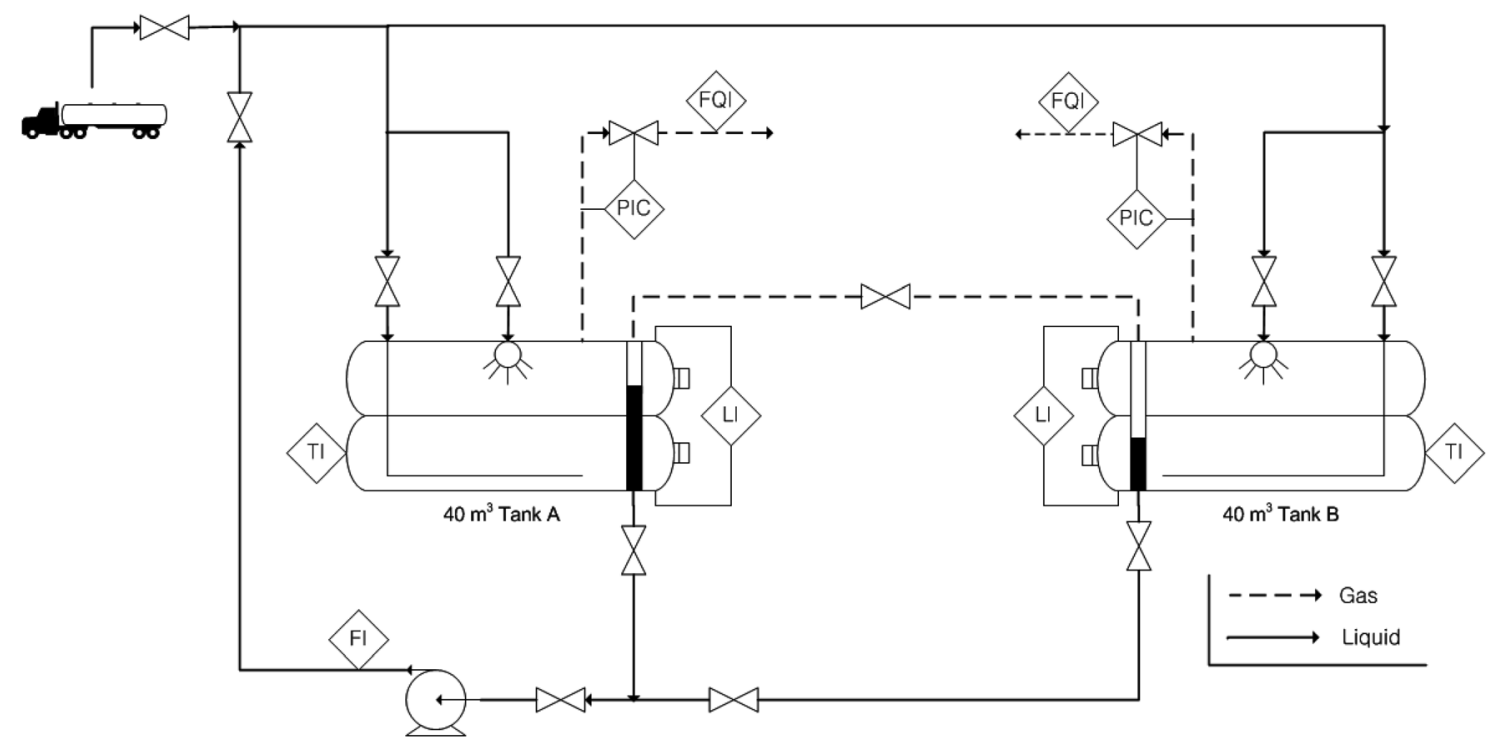

Figure 6. Process diagram of liquefied $\mathrm{CO}_{2}$ storage tanks. 


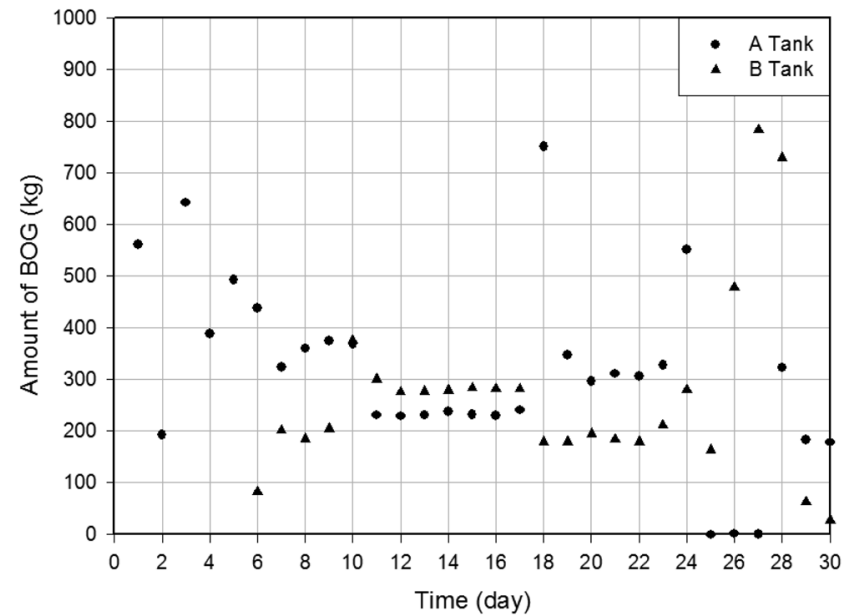

Figure 7. Amount of BOG according to time.

이 미량 포함된 액화 이산화탄소 38 ton을 A Tank에 주입하 였다. 이때 비례적분제어기(proportional-integral controller, $\mathrm{PIC}$ )로 압력을 $20 \mathrm{bar}$ 로 설정하여 충분히 안정화 시킨 뒤, $\mathrm{B}$ Tank에 레벨게이지가 약 $10 \%$ 즉 4 ton을 트랜스퍼하여 두 탱크의 온도와 압력이 같아지도록 이퀄라이징을 하였다. 이 렇게 양 탱크가 안정화 될 때까지 발생하는 $\mathrm{BOG}$ 를 유량기 (flow quality indicator, FQI)을 이용하여 측정하였으며, 안정 화가 되면 압력을 조금씩 변화하여 유체 마찰에 의한 $\mathrm{BOG}$ 발생량도 측정하였다.

또한 선적, 하역의 상황을 가정하여 그때 발생되는 BOG를 측정하였는데, A Tank에 있는 액화 이산화탄소 대부분을 B Tank로 이동하였으며, 이때 A Tank는 하역 B Tank는 선적으 로 보고 그때 발생되는 $\mathrm{BOG}$ 의 양을 측정하였다.

Tank의 상황을 실시간으로 모니터링 하면서 매 2시간마다 각 tank에서 발생한 BOG 양과 압력 및 높이에 따른 온도를 excel을 이용하여 기록하였다. 또한 실험 중 발생한 BOG를 sampling한 뒤 Agilent $7890 \mathrm{~A} \mathrm{GC}$ 를 이용하여 분석하였다. 검출기 는 열전도성 검출기(thermal conductivity detector, TCD)를 사용 하였으며, 분석 회수는 각 tank 당 14회 씩 총 28회 분석하였다.

따라서 30 일간 측정한 $\mathrm{BOG}$ 발생량을 탱크별로 Figure 7과 같이 나타내었다.

10 일째는 처음으로 A tank보다 B tank에서 BOG가 더 많이 발생하는 것을 알 수 있다. 이는 $\mathrm{A} \rightarrow \mathrm{B} \operatorname{tank}$ 로 이동된 지점이 며 대부분의 액화 이산화탄소가 B tank로 옮겨졌기 때문인 것을 알 수 있다. 그리고 18 일째에는 포인트가 다시 역전되는 것을 알 수 있는데, 그 이유는 $\mathrm{B} \rightarrow \mathrm{A} \operatorname{tank}$ 로 다시 이동되었기 때문이다. 또한 26일 이후로는 압력을 조금씩 변화시켜 그때 발생하는 $\mathrm{BOG}$ 를 측정하였으며, 4 일간 $\mathrm{A} \operatorname{tank}$ 는 $3 \mathrm{bar}, \mathrm{B}$ $\operatorname{tank}$ 는 $4 \mathrm{bar}$ 를 감소시켰다. 그 결과 불규칙적으로 상당히 많은 $\mathrm{BOG}$ 가 발생하였으며, B tank에서 약 $800 \mathrm{~kg}$ /day로 1일 기준 $\mathrm{BOG}$ 가 가장 많이 발생하였다.

Figure 8은 시간에 따른 온도, 압력 변화를 나타낸 그래프 로써 양 탱크를 계속 이퀄라이징하면서 실험하였기 때문에 온 도, 압력 모두 변화가 없는 것을 알 수 있다. 하지만 26일 이후인
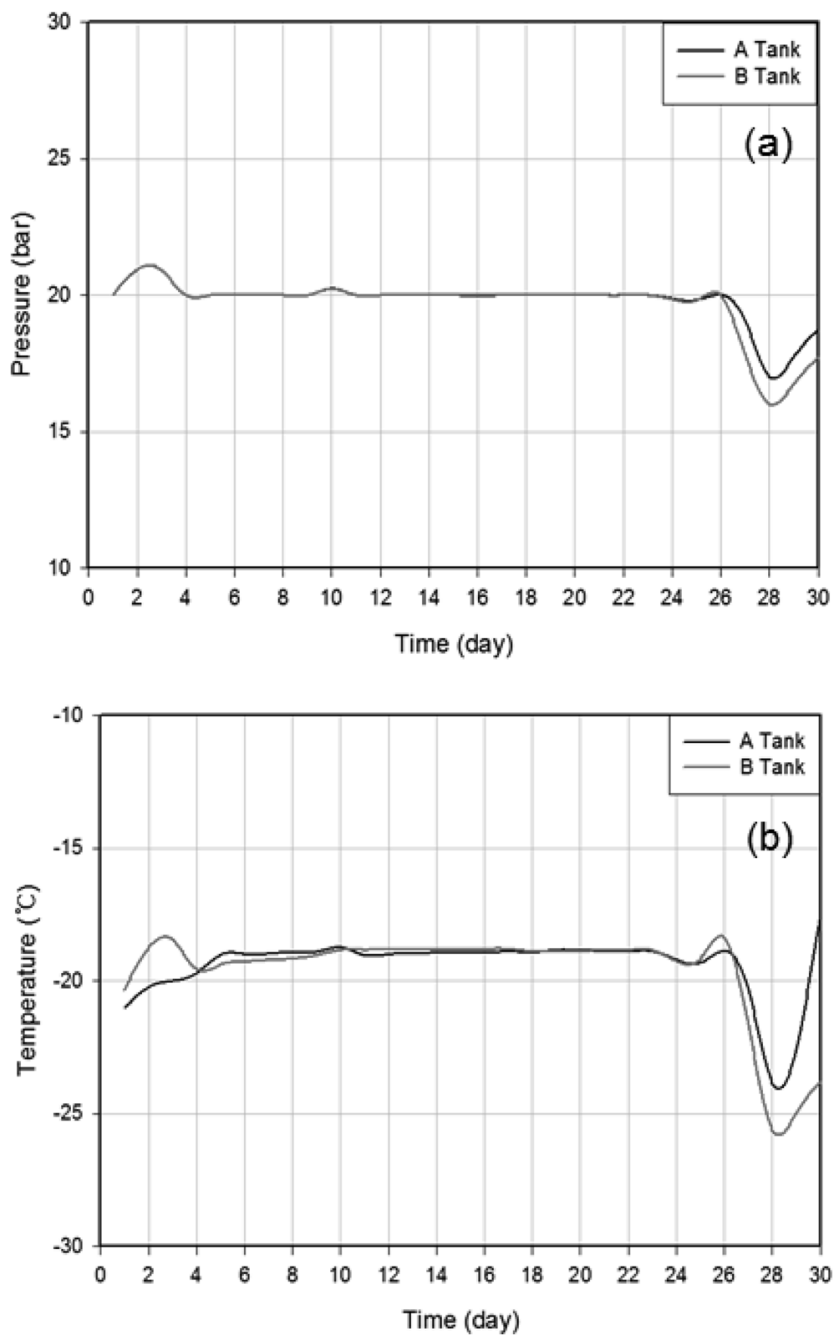

Figure 8. (a) Pressure and (b) temperature change according to time.

Table 2. The result of experiment during 30 days

\begin{tabular}{l|c|c}
\hline & A Tank & B Tank \\
\hline \hline Amount of BOG $(\mathrm{kg})$ & 9,356 & 6,684 \\
\hline Total BOG $(\mathrm{kg})$ & \multicolumn{2}{|c}{16,040} \\
\hline Total BOR & \multicolumn{2}{|c}{0.422} \\
\hline Temperature $\left({ }^{\circ} \mathrm{C}\right)$ & \multicolumn{2}{|c}{$-24--21$} \\
\hline Pressure (bar) & \multicolumn{2}{|c}{$16-20$} \\
\hline Composition of $\mathrm{CO}_{2}(\%)$ & 99.95 & 99.95 \\
\hline Composition of $\mathrm{N}_{2}(\%)$ & 0.05 & 0.05 \\
\hline Average composition $(\%)$ & \multicolumn{2}{|c}{$99.95 / 0.05$} \\
\hline
\end{tabular}

임의로 압력 변화를 줄때는 압력 변화에 따라 온도도 같이 변동하는 것을 알 수 있다.

실험 결과는 Table 2 와 같이 내었으며, 전체 $\mathrm{BOG}$ 는 16,040 $\mathrm{kg}$ 배출하였다. 또한 $\mathrm{BOR}$ 은 0.422 이며 분석 결과 이산화탄소 의 조성이 모두 $99.9 \%$ 이상 포함되었고, 평균 조성은 이산화 탄소는 $99.95 \%$, 질소는 $0.05 \%$ 인 것을 알 수 있었다. 따라서 
$\mathrm{BOR}$ 이 $42.2 \%$ 로 높았으며, 불 응축가스인 질소가 매우 미량 이었기 때문에 재액화 공정을 처리 공정으로 결정하였다.

\section{BOG 재액화 공정모사}

\section{1. 증기 재압축 냉동 사이클}

재액화를 위해서는 냉매를 사용해야 한다. 공정상에서 냉 매의 온도를 낮추는 방법 중 하나인 Joule-Thomson 팽창 밸브 를 사용하여 냉동 사이클을 적용할 수 있다. Figure 9는 압축, 응축, 팽창, 증발 총 4 개로 구성된 증기 재압축 냉동사이클의 개요도이다.

냉매에는 여러 종류가 있지만 수송선에서 새로운 냉매를 사 용하면 별도의 냉매용 탱크를 제작해야 하기 때문에 친환경 냉매인 이산화탄소를 직접 작동유체로 활용하여 냉동사이클 공정모사를 수행하였다.

액화하고자 하는 원료는 BOG가 가장 많이 배출된 지점 $(800 \mathrm{~kg} / \mathrm{day} \rightarrow 33.4 \mathrm{~kg} / \mathrm{h})$ 을 기준으로 하였으며 그 이유는 30 일간 수송 시 최소 필요한 시설과 동력을 알아보기 위함이다. 또한 액화 공정을 통해 온도를 $-40{ }^{\circ} \mathrm{C}$ 까지 낮추어 모두 액
화시키는 것을 목적으로 하였는데 그 이유는 온도를 너무 낮 추면 dry ice의 생성 가능성이 높아지기 때문이다.

\section{2. 공정모사 및 결과}

Figure 10은 상용모사기인 PRO/II with PROVISION version 9.2 를 사용하여 증기 재압축 냉동사이클을 공정모사 한 것이 다. 압축기는 $-10{ }^{\circ} \mathrm{C}$ 에서의 기포점 압력으로 설정하고, 효율 은 $70 \%$ 로 가정하였다. 또한 응축기는 시설인 이산화탄소에 의 해 모두 액화되어야 하기 때문에 액체의 조성을 1 로 설정하 고, 밸브는 $-45{ }^{\circ} \mathrm{C}$ 에서의 이슬점 압력으로 설정하였다.

또한 플래시 드럼을 이용해 단순히 기상과 액상을 분리하 였다. 증발기는 냉매가 열을 흡수하여 모두 기화된다고 가정하 여 액체의 조성을 0 으로 설정하였다. 컨트롤러를 사용하여 원 료가 모두 액화되기 위해 필요한 값을 설정하였다. 공정모사 결과를 Table 3을 이용하여 정리하였다.

그 결과 냉매의 총 순환유량은 $42.07 \mathrm{~kg} / \mathrm{h}$ 가 나왔으며 압축 기의 소요동력은 $0.86 \mathrm{~kW}$, 응축기의 시설 소모량은 $48.85 \mathrm{~kg} / \mathrm{h}$ 가 나오는 것을 알 수 있었다.

Table 3. Results of process simulation based on $33.4 \mathrm{~kg} \mathrm{BOG} \mathrm{per}$ hour

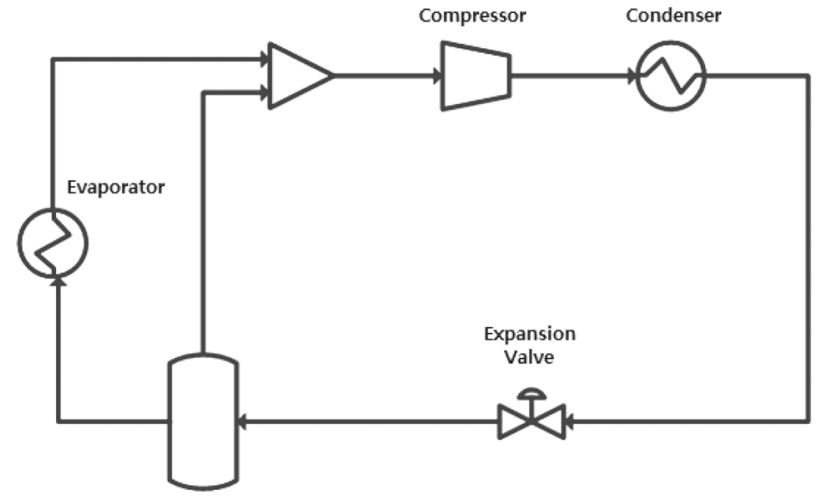

Figure 9. Refrigeration cycle diagram.

\begin{tabular}{l|c}
\hline \multicolumn{1}{c|}{ Contents } & Value \\
\hline \hline Evaporator heat duty $(\mathrm{M} \cdot \mathrm{cal} / \mathrm{h})$ & 2.60 \\
\hline Compressor outlet pressure $(\mathrm{bar})$ & 26.59 \\
\hline Valve outlet pressure $(\mathrm{bar})$ & 8.25 \\
\hline Refrigerant flow for evaporator $(\mathrm{kg} / \mathrm{h})$ & 32.79 \\
\hline Condenser heat duty $(\mathrm{M} \cdot \mathrm{cal} / \mathrm{h})$ & 3.30 \\
\hline Compressor power $(\mathrm{kW})$ & 0.86 \\
\hline Total circulation flow $(\mathrm{kg} / \mathrm{h})$ & 42.07 \\
\hline Utility consumption $(\mathrm{kg} / \mathrm{h})$ & 48.85 \\
\hline
\end{tabular}

\section{4. 결 론}

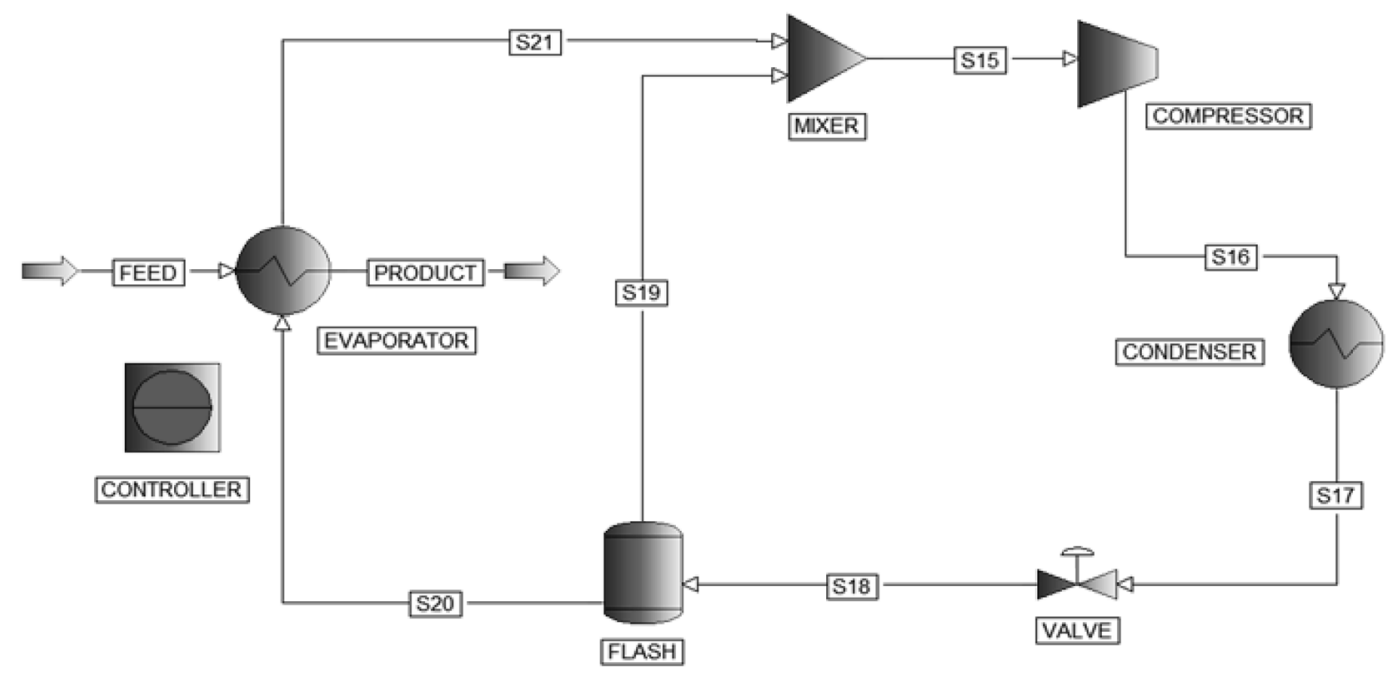

Figure 10. Process simulation of refrigeration cycle using PRO/II with PROVISION version 9.2. 
본 연구에서는 $\mathrm{CCS}$ 기술 중 운반선으로 액화 이산화탄소를 수송 시 저장탱크 내에서 발생하는 $\mathrm{BOG}$ 의 양과 조성을 측정 하였다. 그 결과를 이용하여 $\mathrm{BOG}$ 를 처리하기 위해 재액화 공 정 중 하나인 증기 재압축 냉동사이클을 적용하여 대부분 회 수하는 것을 연구하였으며, 결과는 다음과 같다.

1) 38 ton 액화 이산화탄소를 $-19{ }^{\circ} \mathrm{C}, 20 \mathrm{bar}$ 조건에서 30 일 간 $\mathrm{BOG}$ 의 양을 측정한 결과 $16,040 \mathrm{~kg}$ 이 발생하였다.

2) $\mathrm{BOG}$ 의 조성은 $\mathrm{GC}$ 를 이용하여 분석한 결과 이산화탄소: $99.95 \%$, 질소: $0.05 \%$ 인 것을 알 수 있었다.

3) $\mathrm{BOG}$ 가 가장 많이 발생한 지점인 $800 \mathrm{~kg} / \mathrm{h}$ 를 기준으로 냉동사이클을 적용하여 공정모사 하였으며, 그 결과 냉매의 총 순환유량은 $42.07 \mathrm{~kg} / \mathrm{h}$ 가 나왔으며 압축기의 소요동력은 $0.86 \mathrm{~kW}$, 응축기의 시설 소모량은 $48.85 \mathrm{~kg} / \mathrm{h}$ 가 나오는 것을 알 수 있었다.

\section{감 사}

이 논문은 2013년도 삼성 중공업의 연구비 지원으로 수행되 었으며, 지원에 감사를 드립니다(No.10038671).

\section{References}

1. Yang, Y., and Lee, J. M., "An Iterative Optimization Approach to Design of Control Lyapunov Function," J. Proc. Control., 22(1), 145-155 (2012).

2. Kim, S. H., Koo, J. M., Lee, C. J., and Yoon, E. S., "Optimization of Korean Energy Planning for Sustainability Considering Uncertainties in Learning Rates and External Factors," Eur. Symposium Computer-Aided Proc. Eng., 44(1), 126-134 (2012).

3. Aspelund, A., and Gundersen, T., "A Liquefied Energy Chain for Transport and Utilization of Natural Gas for Power Production with $\mathrm{CO}_{2}$ Capture and Storage-Part 1," Appl. Energy, 86(6), 781-792 (2009).

4. Desideri, U., and Paolucci, A., "Performance Modelling of a Carbon Dioxide Removal System for Power Plants," Energy Conversion Manage., 40(18), 1899-1915 (1999).

5. Aspelund, A., Molnvik, M. J., and Koeijer, G. D., "Ship Transport of $\mathrm{CO}_{2}$ : Technical Solutions and Analysis of Costs, Energy Utilization, Exergy Efficiency and $\mathrm{CO}_{2}$ Emissions," Chem. Eng. Res. Design, 84(9), 847-855 (2006). 